\title{
COST OF AERIAL AND GROUND SPRAYINGS AND TECHNOLOGICAL REPLACEMENT POINT: A CASE STUDY IN THE REGION OF MINEIROS, GO, BRAZIL
}

\author{
Tiago R. Moraes ${ }^{1}$, Vicente M. Cornago Junior ${ }^{1 *}$, \\ Vitor C. R. de Araújo ${ }^{1}$, Maura S. T. Esperancini ${ }^{1}$, Ulisses R. Antuniassi ${ }^{1}$
}

${ }^{1 *}$ Corresponding author. Universidade Estadual Paulista Júlio de Mesquita Filho, Faculdade de Ciências Agronômicas/ Botucatu - SP, Brasil. E-mail: vicente.cornago@hotmail.com | ORCID ID: E-mail: https://orcid.org/0000-0001-7023-4978

\author{
KEYWORDS \\ Efficiency, pesticide \\ spraying, plant \\ crushing, application \\ costs, productivity.
}

\begin{abstract}
One of the main costs in agriculture is related to mechanized operations, which, in turn, are associated with the capital invested in machinery and equipment, the scale of production, and the operating efficiency. Thus, the choice of technology to carry out these operations must take these factors into account to minimize the production cost. In this context, this study aimed to evaluate the most economical investment option for the set of sprayings on a farm located in the municipality of Mineiros, Goiás, Brazil, by comparing two technologies (ground and aerial spraying) and identifying the scale of production that makes each of the technologies more feasible. This study covers the period of one year with the soybean crop in the summer season, followed by the cultivation of corn in the off-season. Economic feasibility indicators were calculated, and the total average costs of both technologies were compared. The results allowed concluding that the investment in aerial spraying with the aircraft acquisition is assertive, as it reduced losses due to crushing. Contracting the service via third parties is feasible and can be used not only in cases of emergency, as it allows for increased profitability.
\end{abstract}

\section{INTRODUCTION}

Agribusiness is a segment of great importance for the Brazilian economy, representing $25 \%$ of the gross domestic product (GDP) in 2018 (Spring, 2018). Efficiency in the production chain, with lower costs and increased productivity, needs to be enhanced to ensure that these numbers grow and continue to contribute significantly to the economy.

Ground and aerial sprayers are essential tools for plant health protection. The most efficient and operationally viable solution for the ground application of pesticides in large areas is self-propelled sprayers. They are capable of covering large areas with precision, showing onboard technology and an operational capacity superior to trailed or mounted sprayers (Farias et al., 2015).

A trend in increasing the size of machinery has been observed in recent decades aiming at a greater operational field capacity, which has led to an increase in the wheelsets and weight of sprayers. This change has aggravated production losses due to damage to the root system, plant crushing, and possible crop contamination due to the presence of pathogens such as fungi and bacteria, which remain in the equipment coming from other sprayed areas. According to Boller, cited by Abi Saab et al. (2007), the reduction in productivity due to damage caused by the use of ground-based equipment can reach up to $2.24 \%$, while Hanna et al. (2007) reported losses between 0.8 and $6.3 \%$.

Another type of possible operation is the application of pesticides using agricultural aircraft, generally carried out in large-scale crops and areas that are not permitted for sprayers to travel over the ground (Antuniassi, 2015). Aerial spraying plays an increasingly important role in the development of precision agriculture due to advantages such as high efficiency and rapid responses in cultivation. In addition, it is an effective means of reducing residues and various environmental impacts, while improving treatment effectiveness (Zhang et al., 2014; Lan et al., 2017).

Agricultural aviation overcomes several limitations of ground application and is a feasible alternative due to its high operational efficiency and satisfactory results at an affordable economic cost (Bayer et al., 2012; Chechetto et

\footnotetext{
${ }^{1}$ Universidade Estadual Paulista Júlio de Mesquita Filho, Faculdade de Ciências Agronômicas/ Botucatu - SP, Brasil.
} 
al., 2014). Also, this type of spraying has advantages such as the elimination of losses by crushing, distribution uniformity, operation under any soil moisture conditions, non-dissemination of plant disease propagules, and a higher concentration of products in the spray solution, which can result in a better effect of some active ingredients (Carvalho \& Cunha, 2019).

Aerial spraying has been growing in Brazil as a viable alternative for pesticide application. In Brazil, more than 73 million hectares are sprayed by agricultural aviation every year, and the number of aircraft increased from 1458 in 2008 to 2134 in 2018, which represents a growth of $46.4 \%$ in the period (Araújo, 2019).

However, farmers still do not feel confident in contracting the aerial spraying service or even purchasing their own aircraft even though this modality has advantages over ground spraying. Possibly, the lack of information on the economy of the operation should contribute to the resistance to the use of agricultural aviation. In this sense, cost analysis is essential to support producers in their decision-making, as any cost reduction contributes to increasing the profitability of crops due to the narrow profitability margin in agriculture (Oliveira et al., 2012; Artuzo et al., 2018).

Therefore, this study aimed to determine the feasibility of acquiring aircraft for aerial spraying, the minimum area that makes the use of this technology economically feasible, and the feasibility of the outsourced service, using a grain cultivation farm as the study model.

\section{MATERIAL AND METHODS}

The analysis of the decision-making process for choosing the spraying technology was carried out using a farm, located in Mineiros, Goiás, Brazil, as a model for the case study. This farm produced 6,000 ha of soybean and corn (off-season) in the 2018/19 growing season. The annual agricultural calendar foresees an average of seven applications for soybean cultivation and five applications for corn cultivation, totaling twelve spraying operations currently carried out on the farm by four self-propelled ground sprayers.

The total sprayed area (TSA) by ground sprayers consisted of 72,000 ha (18,000 ha for each ground sprayer), considering the total area size $(6,000 \mathrm{ha})$ and the number of operations (12). Due to the presence of places where aerial spraying is prohibited, the potential area for this type of spraying in this study was 5,400 hectares, that is, 64,800 hectares considering the number of operations.

The data for defining the working hours $(\mathrm{WH})$ were provided by the farm, according to the previous experience of the farmer and technicians, being 8 hours daily for ground spraying and 5 hours daily for aerial spraying.

Operational information collected on the farm (Vilela, 2019) showed that the four ground-based sprayers can apply to the total area of the property in four and a half days, on average, representing a balance between the desired speed of work ("the faster the better") and the possibilities of the available machinery without the risk of productivity losses. Thus, the maximum amount of four and a half days was considered for the application window (AW), as it is the maximum number of days required by the farm, resulting in the largest total area that each aerial sprayer has the potential to spray (TSA).
The operational field capacity (OFC) was calculated from the dimensional data of each self-propelled sprayer, considering 45 ha/hour. These values were provided by the aircraft manufacturers, as follows: 100 ha/hour for the Embraer Ipanema 202-A, 130 ha/hour for the Embraer Ipanema 203 (Generoso, 2019), 190 ha/hour for the Air Tractor 402-B, and 220 ha/hour for the Air Tractor 502-B (Silva, 2019).

The total area that each aerial sprayer has the potential to spray (TSA) for the calculation of fixed and variable costs was calculated from the working hours (WH), operational field capacity (OFC), application window (AW), and the number of operations (12) (Equation 1) and considered 28,200 ha of total sprayed area for the Embraer Ipanema 202-A, 36,660 ha of total sprayed area for the Embraer Ipanema 203, 53,580 ha of total sprayed area for the Air Tractor 402-B, and 62,040 ha of total sprayed area for the Air Tractor 502-B.

$$
\mathrm{TSA}(\text { ha })=\mathrm{WH}(\text { hours }) \times \mathrm{OFC}(\text { ha } / \text { hour }) \times \mathrm{AW}(\text { days }) \times 12
$$

Productivity losses resulting from the crushing caused by the movement of the ground sprayer during the spraying operations throughout the soybean growing season were quantified using the estimates of Abi Saab et al. (2007) and Camargo et al. (2008), who observed values lower than or equal to $1 \%$. Thus, the value of $1 \%$ was defined because the farm minimizes the crop crushing as much as possible by using a GPS, autopilot, regulation of the distance between wheels, and larger boom size, which increases the precision and efficiency of the operations.

The corn plant has low plasticity, which means that there is no compensation for the production of affected plants, thus presenting higher values of losses by crushing compared to the soybean crop. Oliveira \& Dalchiavon (2019) defined economic losses by crushing 3\% for soybean and $5 \%$ for corn. It shows that corn has a crushing $67 \%$ higher according to these authors. Thus, the percentage of loss for the corn crop was set at $1.67 \%$, that is, $67 \%$ higher than that proposed by Abi Saab et al. (2007) and Camargo et al. (2008).

Productivity and sale values provided by the farm in the 2018/19 growing season were used to quantify the costs of losses by crushing, which consisted of 65 bags of soybean/ha at R\$66.00/bag and 150 bags of corn/ha at R\$ 25.00/bag.

The total costs (TC) of ground and aerial spraying operations were estimated using a methodology adapted from the standards of ASABE (American Society of Agricultural Engineers), which considers fixed (FC) and variable costs (VC) (ASABE, 2011). Fixed costs refer to costs of ownership and are associated with fixed assets in the investment in ground and aerial sprayers (depreciation, interest rate on fixed capital, fees and taxes, housing, insurance, and labor). On the other hand, variable costs are associated with the use of the equipment. The variable costs for ground sprayers consisted of fuel, lubricants, maintenance, and losses due to crushing. The variable costs of aerial sprayers were determined considering the fuel, lubricants, labor, and spare parts, engine overhaul, and propeller overhaul.

The value of the asset was determined through information provided by the farm, such as the year the sprayer was purchased, the number of hours worked, and 
the state of conservation, allowing the market analysis at different dealerships. Thus, the asset value was defined according to the values found in the region, as follows: $\mathrm{R} \$$ 950,000.00 (Sprayer 1), R\$ 800,000.00 (Sprayer 2), R\$ $750,000.00$ (Sprayer 3), and R\$ 700,000.00 (Sprayer 4).

The calculation of fixed costs considered fees and taxes of $1.5 \%$ of the asset value, housing of $1 \%$ of the asset value, insurance of $1.2 \%$ of the asset value, and a lifespan of 10 years (ASABE, 2011). A scrap value of $20 \%$ of the asset value was defined based on market analysis and dealership information, with the interest rate defined in accordance with the Brazilian SELIC rate, that is, 5.4\% per year in 2019. The cost of labor consisted of $\mathrm{R} \$ 3,500.00$ per month paid by the farm for each operator of ground sprayers, considering the salary and bonuses paid in the 2019/20 growing season (Vilela, 2019).

The calculation of the variable costs of ground sprayers considered 1600 hours the total hours worked (THW) for spraying 72,000 ha (Equation 2). Fuel consumption reached $30 \mathrm{~L} /$ hour and lubricants accounted for $15 \%$ of the fuel consumption (ASABE, 2011). Maintenance expenses were R\$12,750.00 per year for each sprayer (Vilela, 2019), while productivity loss due to crushing was $1.00 \%$ for soybean and $1.67 \%$ for corn (Abi Saab et al., 2007; Camargo et al., 2008; Oliveira \& Dalchiavon 2019).

$$
\text { THW (hours) }=\frac{\text { TSA (ha) }}{\text { OFC (ha/hour) }}
$$

The data for the composition of fixed and variable costs of aerial spraying were provided by Embraer for Ipanema 202A and Ipanema 203 aircraft, with purchase values of $\mathrm{R} \$ 1,650,000.00$ and $\mathrm{R} \$ 1,714,500.00$, respectively, and Aeroglobo Aeronaves for Air Tractor 402$\mathrm{B}$ and Air Tractor 502-B aircraft, with purchase values of $\mathrm{R} \$ 3,423,317.90$ and $\mathrm{R} \$ 3,952,825.40$, respectively.

The fixed costs of the aircraft were composed of fees and taxes of $1.5 \%$ of the asset value, housing of $1 \%$ of the asset value, and insurance of $4 \%$ of the asset value (ASABE, 2011). The lifespan of 20 years and scrap value of $40 \%$ of the asset value, used to calculate the depreciation, were obtained through information provided by the companies Aeroglobo and Embraer, in addition to market analysis. The interest rate was in accordance with the SELIC rate of $5.4 \%$ per year in 2019. The amortization (50\% in 10 years) was defined according to the producer conditions and needs. The value of labor for agricultural pilots was $\mathrm{R} \$ 2.70$ per sprayed hectare for Ipanema models (Generoso, 2019) and R\$ 1.50 per sprayed hectare for Air Tractor models (Silva, 2019).

The total hours worked (THW) for spraying the total potential area (TSA) and the operational field capacity (OFC) of each aircraft were considered to calculate the variable costs of aerial sprayers (Equation 2).

The data for calculating variable costs were different between Ipanema and Air Tractor aircraft. In this sense, the Ipanema 202A and 203 aircraft had a fuel consumption of 100 L/hour (Ipanema 202A) and 120 L/hour (Ipanema 203), lubricants of $0.48 \mathrm{~L} /$ hour, costs of labor and spare parts of $\mathrm{R} \$ 25.00 /$ hour, engine overhaul of $\mathrm{R} \$ 93.33 /$ hour, and propeller overhaul of $\mathrm{R} \$ 4.60 /$ hour. The data for the Air Tractor 402-B were fuel consumption of $200 \mathrm{~L} / \mathrm{hour}$, lubricants of $0.03 \mathrm{~L} /$ hour, costs of labor and spare parts of $\mathrm{R} \$ 26.00 /$ hour, engine overhaul of $\mathrm{R} \$ 178.00 /$ hour, and propeller overhaul of R $\$ 9.50 /$ hour. Moreover, the data for the Air Tractor 502-B were fuel consumption of $230 \mathrm{~L} / \mathrm{hour}$, lubricants of $0.03 \mathrm{~L} /$ hour, costs of labor and spare parts of $\mathrm{R} \$ 28.00 /$ hour, engine overhaul of $\mathrm{R} \$ 155.70 /$ hour, and propeller overhaul of $\mathrm{R} \$ 9.50 /$ hour (Martin, 2019).

The production cost $(\mathrm{PC})(\mathrm{R} \$ /$ ha) (Equation 3) was defined by dividing the hourly cost (HC) (R $\$ /$ hour) (Equation 4) by the operational field capacity (OFC) (ha/hour). The total number of hours worked (THW) (hour) (Equation 5) was defined by dividing the total sprayed area (TSA) (ha) by the operational field capacity (OFC) (ha/hour).

$$
\mathrm{PC}(\mathrm{R} \$ / \mathrm{ha})=\frac{\mathrm{HC}(\mathrm{R} \$ \text { hour })}{\mathrm{OFC}(\text { ha/hour })}
$$

$$
\mathrm{HC}(\mathrm{R} \$ / \text { hour })=\frac{\mathrm{TC}(\mathrm{FC}+\mathrm{VC})(\mathrm{R} \$)}{\mathrm{THW}(\text { hours })}
$$

Where:

$$
\text { THW (hours) }=\frac{\text { TSA (ha) }}{\text { OFC (ha/hour) }}
$$

TSA (ha) is the cultivated area of the farm multiplied by the number of operations, and

OFC (ha/hour) is equal to $100 \mathrm{ha} /$ hour for the Ipanema 202-A aircraft, $130 \mathrm{ha} /$ hour for the Ipanema 203 aircraft, $190 \mathrm{ha} /$ hour for the AT 402-B aircraft, 220 ha/hour for the AT 502-B aircraft, and 45 ha/hour for the ground sprayer.

The economic feasibility of aircraft acquisition was estimated using the Crepaldi (2016) technique by calculating the net present value (NPV) (Equation 6), the internal rate of return (IRR), and payback, the latter corresponding to the period to recover the investment. The period used to calculate these indicators was 10 years (Crepaldi, 2016).

$$
\mathrm{NPV}=\mathrm{CF}_{0}+\frac{\mathrm{CF}_{1}}{(1+\mathrm{MARR})^{1}}+\frac{\mathrm{CF}_{2}}{(1+\mathrm{MARR})^{2}}+\cdots+\frac{\mathrm{CF}_{\mathrm{n}}}{(1+\mathrm{MARR})^{\mathrm{n}}}
$$

Where:

NPV is the sum of the present value of all expected cash flows from the aircraft acquisition, indicating whether the investment is feasible or not;

$\mathrm{CF}_{0}$ is the cash flow in the zero period, that is, the initial investment (Equation 7);

$\mathrm{CF}_{\mathrm{n}}$ is the cash flow in a given period $\mathrm{n}$;

MARR is the minimum attractive rate of return, which is the discount rate used to represent the minimum value that an investment must obtain, and $\mathrm{n}$ is the number of periods.

$$
\mathrm{CF}_{0}=\frac{\mathrm{CF}_{1}}{(1+\mathrm{i})^{1}}+\frac{\mathrm{CF}_{2}}{(1+\mathrm{i})^{2}}+\cdots+\frac{\mathrm{CF}_{\mathrm{n}}}{(1+\mathrm{i})^{\mathrm{n}}}
$$

Where:

$\mathrm{CF}_{0}$ is the cash flow in the zero period, that is, the initial investment;

$\mathrm{CF}_{\mathrm{n}}$ is the cash flow in a given period $\mathrm{n}$; 
$i$ is the internal rate of return (IRR), and

IRR is the rate that equalizes the investment value (cash outflow) with the value of one or more receipts (cash inflows).

The minimum attractive rate of return (MARR) is the rate applied to the project, representing what is not gained by not investing the capital to be invested in an alternative available on the market (Faro, 1979). The MARR used was $7 \%$, considering the importance of the present study in terms of economic, environmental, and social aspects.

The calculation of these economic indicators considered the grain production of the farm in the scenario of the 2018/19 growing season (Scenario 1), which showed a loss in productivity due to crushing in the total area caused by ground spraying on soybean and corn crops. Subsequently, grain production was calculated for the area with the crushing of crops due to ground spraying and the area without crushing of the crops due to aerial spraying (Scenario 2).

The difference between grain production only with ground spraying (Scenario 1) and grain production using ground spraying associated with aerial spraying (Scenario 2) resulted in an increment in grain production, increasing the farm net profit (NP) (Equation 8). The difference between the total costs of Scenario 1 (TC Scenario 1) and Scenario 2 (TC Scenario 2) was deducted from net profit (NP), resulting in the adjusted net profit (ANP) (Equation 9), which was used to compose the cash flow.

$$
\mathrm{NP}=\text { Scenario } 1-\text { Scenario } 2
$$

$$
\mathrm{ANP}=\mathrm{NP}-(\mathrm{TC} \text { Scenario } 2-\mathrm{TC} \text { Scenario } 1)
$$

The average total costs of the operations were estimated using fixed and variable costs and the potential area to be sprayed (Equation 10). The method of variation in cost due to use was used to determine the minimum area that enables the replacement of the ground for the aerial technology (Hoffmann et al., 1989).

$$
\frac{\mathrm{TFC}_{\mathrm{G}}}{\mathrm{Y}}+\mathrm{K}_{\mathrm{G}}=\frac{\mathrm{TFC}_{\mathrm{A}}}{\mathrm{Y}}+\mathrm{K}_{\mathrm{A}}
$$

Where:

$\mathrm{TFC}_{\mathrm{G}}$ is the total fixed cost of ground spraying (R\$/ha);

$\mathrm{K}_{\mathrm{G}}$ is a constant that indicates the average variable cost of ground spraying ( $\mathrm{R} \$ / \mathrm{ha})$;

$\mathrm{TFC}_{\mathrm{A}}$ is the total fixed cost of aerial spraying ( $\mathrm{R} \$ / \mathrm{ha})$;

$\mathrm{K}_{\mathrm{A}}$ is a constant that indicates the average variable cost of aerial spraying ( $\mathrm{R} \$ / \mathrm{ha})$, and

$\mathrm{Y}$ is the minimum area that compensates the replacement of the ground for the aerial system (ha).

\section{RESULTS AND DISCUSSION}

The total cost of ground spraying was obtained from the sum of fixed (Table 1) and variable costs (Table 2) of the four ground sprayers and reached $\mathrm{R} \$ 874,200.00$, that is, $\mathrm{R} \$ 218,550.00$ for each sprayer. The total cost of each aerial sprayer was obtained from the sum of fixed (Table 3 ) and variable costs (Table 4), reaching different values according to the aircraft model, as follows: $\mathrm{R} \$ 460,339.00$ for Ipanema 202A, R \$ 509,605.48 for Ipanema 203, R\$ 907,917.43 for Air Tractor 402-B, and R\$ 1,032,401.93 for Air Tractor 502-B.

TABLE 1. Fixed costs of ground spraying in the area of 72,000 hectares (2018/19 growing season).

\begin{tabular}{lcccc}
\hline & Sprayer 1 & Sprayer 2 & Sprayer 3 & Sprayer 4 \\
\hline Depreciation $(\mathrm{R} \$)$ & $76,000.00$ & $64,000.00$ & $60,000.00$ & $56,000.00$ \\
Interest rate $(\mathrm{R} \$)$ & $20,520.00$ & $17,280.00$ & $16,200.00$ & $15,120.00$ \\
Fees and taxes $(\mathrm{R} \$)$ & $14,250.00$ & $12,000.00$ & $11,250.00$ & $10,500.00$ \\
Housing $(\mathrm{R} \$)$ & $9,500.00$ & $8,000.00$ & $7,500.00$ & $7,000.00$ \\
Insurance $(\mathrm{R} \$)$ & $11,400.00$ & $9,600.00$ & $9,000.00$ & $8,400.00$ \\
Labor $(\mathrm{R} \$)$ & $48,000.00$ & $48,000.00$ & $48,000.00$ & $48,000.00$ \\
\hline Total $(\mathrm{R} \$)^{1}$ & $179,670.00$ & $158,880.00$ & $151,950.00$ & $145,020.00$ \\
\hline
\end{tabular}

${ }^{1}$ The total fixed cost (sum of all costs for the four sprayers) was $\mathrm{R} \$ 635,520.00$.

TABLE 2. Variable costs of ground spraying in the area of 72,000 hectares (2018/19 growing season).

\begin{tabular}{lc}
\hline & 1600 hours worked $^{1}$ \\
\hline Fuel $(\mathrm{R} \$)^{2}$ & $163,200.00$ \\
Lubricant $(\mathrm{R} \$)$ & $24,480.00$ \\
Maintenance $(\mathrm{R} \$)$ & $51,000.00$ \\
\hline Total $(\mathrm{R} \$)^{3}$ & $238,680.00$ \\
\hline${ }^{1} \mathrm{~A}$ total of 1,600 hours is required to carry out ground spraying considering the total area (72,000 ha) and operational field capacity (45 \\
ha/hour). \\
${ }^{2}$ The variable costs (fuel, lubricant, and maintenance) refer to 1,600 hours. \\
${ }^{3}$ The total variable cost of the four sprayers was $\mathrm{R} \$ 238,680.00$.
\end{tabular}


TABLE 3. Fixed costs of aerial spraying in the area of 72,000 hectares (2018/19 growing season).

\begin{tabular}{lcccc}
\hline & Ipanema 202A & Ipanema 203 & AT 402-B & AT 502-B \\
\hline Depreciation (R\$) & $49,500.00$ & $51,435.00$ & $102,700.00$ & $118,585.00$ \\
Amortization (R\$) & $82,500.00$ & $85,725.00$ & $171,166.00$ & $197,641.00$ \\
Interest rate (R\$) & $26,730.00$ & $27,774.90$ & $55,457.75$ & $64,035.77$ \\
Fees and taxes (R\$) & $24,750.00$ & $25,717.50$ & $51,349.77$ & $59,292.38$ \\
Housing (R\$) & $16,500.00$ & $17,145.00$ & $34,233.18$ & $39,528.26$ \\
Insurance (R\$) & $66,000.00$ & $68,580.00$ & $136,932.72$ & $158,113.02$ \\
Labor (R\$) & $76,923.00$ & $100,000.00$ & $80,370.00$ & $93,060.00$ \\
\hline Total (R\$) & $342,903.00$ & $376,377.40$ & $632,209.42$ & $730,255.43$ \\
\hline
\end{tabular}

TABLE 4. Variable costs of aerial spraying in the area of 72,000 hectares (2018/19 growing season).

\begin{tabular}{lcccc}
\hline & Ipanema 202A & Ipanema 203 & AT 402-B & AT 502-B \\
\hline Fuel (R\$) & $78,960.00$ & $94,752.00$ & $214,320.00$ & $246,468.00$ \\
Lubricant (R\$) & $3,790.08$ & $3,790.08$ & $1,184.40$ & $1,184.40$ \\
Labor and spare parts (R\$) & $7,050.00$ & $7,050.00$ & $7,332.00$ & $7,896.00$ \\
Engine overhaul (R\$) & $26,320.00$ & $26,320.00$ & $50,193.00$ & $43,919.00$ \\
Propeller review (R\$) & $1,316.00$ & $1,316.00$ & $2,679.00$ & $2,679.00$ \\
\hline Total $(\mathrm{R} \$)$ & $117,436.08$ & $133,228.08$ & $275,708.40$ & $302,146.40$ \\
\hline
\end{tabular}

The revenue from the sale of grains in the 2018/19 growing season was $\mathrm{R} \$ 48,240,000$ (Table 5). Considering the mechanical damage losses of 1.00 and $1.67 \%$ in the production of soybean and corn, respectively (Abi Saab et al., 2007; Camargo et al., 2008; Oliveira \& Dalchiavon, 2019), the estimated cost of crushing loss was $\mathrm{R} \$ 8.79$ per hectare (Table 6), which corroborates with the studies conducted by Oliveira et al. (2014).

TABLE 5. Revenue of the farm from grain sales (2018/19 growing season).

\begin{tabular}{ccccc}
\hline Crop & $\begin{array}{c}\text { Area } \\
\text { (ha) }\end{array}$ & $\begin{array}{c}\text { Productivity } \\
\text { (bags of 60 kg/ha) }\end{array}$ & $\begin{array}{c}\text { Price } \\
\text { (R\$) }\end{array}$ & $\begin{array}{c}\text { Total } \\
\text { (R\$) }\end{array}$ \\
\hline Soybean & $6,000^{1}$ & 65 & 66.00 & $25,740,000$ \\
Corn & $6,000^{1}$ & 150 & 25.00 & $22,500,000$ \\
\hline Total $(\mathrm{R} \$)$ & & & & $48,240,000$ \\
\hline
\end{tabular}

${ }^{1}$ The area represents 72,000 sprayed hectares.

TABLE 6. Crushing loss in the total area of 72,000 sprayed hectares (2018/19 growing season).

\begin{tabular}{ccccc}
\hline Crop & Production $(\mathrm{kg})$ & Crushing $(\%)$ & Loss $(\mathrm{R} \$)$ & Loss $(\mathrm{R} \$ / \mathrm{ha})$ \\
\hline Soybean & 390,000 & $1.00 \%$ & 257,400 & 3.58 \\
Corn & 900,000 & $1.67 \%$ & 375,750 & 5.22 \\
\hline Total $(\mathrm{R} \$)$ & & & 633,150 & 8.79 \\
\hline
\end{tabular}

According to Martin (2019), an agricultural aircraft flies, on average, 500 hours per year. Table 7 shows that the aircraft had only 282 flight hours due to the estimated potential area. The production costs were slightly higher than those found by Antuniassi (2015) because of the aircraft underutilization.

Table 7 also shows that at least two ground sprayers were needed to replace a model of the aerial sprayers Ipanema 203, AT 402-B, and AT 502-B, as a ground sprayer has the potential to spray 18,000 ha and, therefore, two ground sprayers have the potential to spray 36,000 hectares, while the aerial sprayers Ipanema 203, AT 402-B, and AT $502-\mathrm{B}$ have the potential to spray $36,660,53,580$, and 62,040 ha, respectively.

Thus, considering the production cost of a ground spray of $\mathrm{R} \$ 12.14$ and two ground sprayers of $\mathrm{R} \$ 24.28$, the production cost of ground spraying was higher, as two ground sprayers were required to replace one aerial sprayer in this case study. 
TABLE 7. Production costs of ground and aerial sprayers according to the potential spraying area for each type of sprayer (2018/19 growing season).

\begin{tabular}{lccccc}
\hline & GROUND $^{2}$ & IPANEMA 202-A & IPANEMA 203 & AT 402-B & AT 502-B \\
\hline Asset value (R\$) & 800,000 & $1,650,000$ & $1,714,500$ & $3,423,317.90$ & $3,952,825.40$ \\
Lifespan (years) & 10 & 20 & 20 & 20 & 20 \\
Potential area (ha) & 18,000 & 28,200 & 36,660 & 53,580 & 62,040 \\
Operational capacity (ha/hour) & 45 & 100 & 130 & 190 & 220 \\
Hours worked (hour) & 400 & 282 & 282 & 282 & 282 \\
Hourly cost (R $\$$ hora) & 546.37 & $1,632.40$ & $1,807.11$ & $3,219.56$ & $3,660.99$ \\
\hline Production cost (R $/$ ha) & 12.14 & 16.32 & 13.90 & 16.94 & 16.64 \\
\hline
\end{tabular}

${ }^{1}$ Total area that each sprayer has the potential to spray.

${ }^{2}$ The average value of the four ground sprayers was considered in the analysis.

The increased net profit (NP) of the farm when using ground spraying associated with aerial spraying for the different models was $\mathrm{R} \$ 247,983.75$ for Ipanema $202 \mathrm{~A}$
(Table 8), R \$322,378.88 for Ipanema 203 (Table 9), R \$ $471,169.13$ for AT 402-B (Table 10), and R \$ 545,564.25 for AT 502-B (Table 11).

TABLE 8. Difference in production with the use of ground spraying associated with aerial spraying (Ipanema 202A) and ground spraying alone (2018/19 growing season).

\begin{tabular}{ccccc}
\hline Crop & $\begin{array}{c}\text { Aerial and ground spraying } \\
(\text { production in } \mathrm{kg})^{1}\end{array}$ & $\begin{array}{c}\text { Ground spraying } \\
(\text { production in } \mathrm{kg})^{2}\end{array}$ & $\begin{array}{c}\text { Difference } \\
(\mathrm{kg})\end{array}$ & $\begin{array}{c}\text { Difference } \\
(\mathrm{R} \$)\end{array}$ \\
\hline Soybean & $387,627.50$ & 386,100 & $1,527.50$ & $100,815.00$ \\
Corn & $890,856.75$ & 884,970 & $5,886.75$ & $147,168.75$ \\
\hline Total $(\mathrm{R} \$)$ & & & & $247,983.75$ \\
\hline
\end{tabular}

${ }^{1}$ Aerial spraying without crushing (28,200 ha) and ground spraying with crushing (43,800 ha).

${ }^{2}$ Ground spraying with crushing in the total spraying area (72,000 ha).

TABLE 9. Difference in production with the use of ground spraying associated with aerial spraying (Ipanema 203) and ground spraying alone (2018/19 growing season).

\begin{tabular}{ccccc}
\hline Crop & $\begin{array}{c}\text { Aerial and ground spraying } \\
(\text { production in } \mathrm{kg})^{1}\end{array}$ & $\begin{array}{c}\text { Ground spraying } \\
(\text { production in } \mathrm{kg})^{2}\end{array}$ & $\begin{array}{c}\text { Difference } \\
(\mathrm{kg})\end{array}$ & $\begin{array}{c}\text { Difference } \\
(\mathrm{R} \$)\end{array}$ \\
\hline Soybean & $388,085.75$ & 386,100 & $1,985.75$ & $131,059.50$ \\
Corn & $892,622.77$ & 884,970 & $7,652.77$ & $191,319.37$ \\
\hline Total $(\mathrm{R} \$)$ & & & & $322,378.88$
\end{tabular}

${ }^{1}$ Aerial spraying without crushing (36,660 ha) and ground spraying with crushing (35,340 ha).

${ }^{2}$ Ground spraying with crushing in the total spraying area (72,000 ha).

TABLE 10. Difference in production with the use of ground spraying associated with aerial spraying (AT 402-B) and ground spraying alone (2018/19 growing season).

\begin{tabular}{ccccc}
\hline Crop & $\begin{array}{c}\text { Aerial and ground spraying } \\
(\text { production in } \mathrm{kg})^{1}\end{array}$ & $\begin{array}{c}\text { Ground spraying } \\
(\text { production in } \mathrm{kg})^{2}\end{array}$ & $\begin{array}{c}\text { Difference } \\
(\mathrm{kg})\end{array}$ & $\begin{array}{c}\text { Difference } \\
(\mathrm{R} \$)\end{array}$ \\
\hline Soybean & $389,002.25$ & 386,100 & $2,902.25$ & $191,548.50$ \\
Corn & $896,154.82$ & 884,970 & $11,184.82$ & $279,620.62$ \\
\hline
\end{tabular}

Total (R\$) $471,169.13$

${ }^{1}$ Aerial spraying without crushing (53,580 ha) and ground spraying with crushing (18,420 ha).

${ }^{2}$ Ground spraying with crushing in the total spraying area (72,000 ha).

TABLE 11. Difference in production with the use of ground spraying associated with aerial spraying (AT 502-B) and ground spraying alone (2018/19 growing season).

\begin{tabular}{ccccc}
\hline Crop & $\begin{array}{c}\text { Aerial and ground spraying } \\
(\text { production in } \mathrm{kg})^{1}\end{array}$ & $\begin{array}{c}\text { Ground spraying } \\
(\text { production in } \mathrm{kg})^{2}\end{array}$ & $\begin{array}{c}\text { Difference } \\
(\mathrm{kg})\end{array}$ & $\begin{array}{c}\text { Difference } \\
(\mathrm{R} \$)\end{array}$ \\
\hline Soybean & $389,460.50$ & 386,100 & $3,360.50$ & $221,793.00$ \\
Corn & $897,920.85$ & 884,970 & $12,950.85$ & $323,771.25$ \\
\hline Total $(\mathrm{R} \$)$ & & & & $545,564.25$
\end{tabular}

${ }^{1}$ Aerial spraying without crushing (62,040 ha) and ground spraying with crushing (9,960 ha).

${ }^{2}$ Ground spraying with crushing in the total spraying area (72,000 ha). 
The total cost $(\mathrm{FC}+\mathrm{VC})$ of ground spraying associated with aerial spraying was obtained by the combination of three ground sprayers with one Ipanema 202A, two ground sprayers with one Ipanema 203, one ground sprayer with one AT 402-B, and one ground sprayer with one AT 502-B (Table 12). The number of ground sprayers together was different because the models have different potential spraying areas.

TABLE 12. Total costs of ground spraying associated with aerial spraying for the different models.

\begin{tabular}{cc}
\hline Sets & Total cost $(\mathrm{R} \$)$ \\
\hline 3 ground sprayers + Ipanema 202A & $997,548.00$ \\
2 ground sprayers + Ipanema 203 & $944,517.58$ \\
1 ground sprayer + AT 402-B & $1,126,467.43$ \\
1 ground sprayer + AT 502-B & $1,210,438.93$ \\
\hline
\end{tabular}

The total cost $(\mathrm{FC}+\mathrm{VC})$ of the four ground sprayers in the scenario of the farm under study was $\mathrm{R} \$ 874,200.00$. Thus, the total cost of ground spraying associated with aerial spraying (Scenario 2) was more expensive in all sets than the ground spraying alone (Scenario 1), with this value being discounted from the net profit (NP), resulting in the adjusted net profit (ANP) (Table 13).

TABLE 13. Difference between the total cost of ground spraying associated with aerial spraying and the total cost of ground spraying to obtain the adjusted net profit.

\begin{tabular}{lccccc}
\hline \multicolumn{1}{c}{ Sets } & Total cost & Ground cost & Difference & NP & ANP \\
\hline Ipanema 202A + 3 ground sprayers & $997,548.00$ & $874,200.00$ & $123,348.00$ & $247,983.75$ & $124,635.75$ \\
Ipanema 203 + 2 ground sprayers & $944,517.58$ & $874,200.00$ & $70,317.58$ & $322,378.88$ & $252,061.30$ \\
AT 402-B + 1 ground sprayer & $1,126,467.43$ & $874,200.00$ & $252,267.43$ & $471,169.13$ & $218,901.70$ \\
AT 502-B + 1 ground sprayer & $1,210,438.93$ & $874,200.00$ & $336,238.93$ & $545,564.25$ & $209,325.32$ \\
\hline
\end{tabular}

Therefore, the adjusted net profit of each set allowed calculating the feasibility of investing in aircraft through the economic indicators net present value (NPV), internal rate of return (IRR), and payback (Table 14).

TABLE 14. Economic indicators of the aircraft investment.

\begin{tabular}{lcccc}
\hline & Ipanema 202A & Ipanema 203 & AT 402-B & AT 502-B \\
\hline NPV (R\$) & $-774,610.65$ & $55,873.09$ & $-1,885,843.96$ & $-2,482,611.95$ \\
IRR (\%) & $-5 \%$ & $8 \%$ & $-7 \%$ & $-10 \%$ \\
PB (years) & 13.23 & 6.80 & 15.63 & 18.88 \\
\hline
\end{tabular}

The investment in aerial spraying may be feasible, as observed by Oliveira \& Dalchiavon (2019), as NPV was positive, and IRR was higher than the MARR of $7 \%$ for the Ipanema 203 model. In addition, payback (PB) indicated that the investment will be paid in 6.80 years.

The Ipanema 202A model presented an economic infeasibility due to its lower operational field capacity, as it needs three ground sprayers together, which increased the costs when compared to Ipanema 203, which presents a better adaptation to the size of the sprayed area in terms of the application window, production cost, investment volume, and operational field capacity. The models AT 402-B and 502-B were economically unfeasible in this case study due to the high investment value, high total cost (FC $+\mathrm{VC}$ ), and their underutilization.

The calculation of the total average costs showed that replacement of ground for aerial spraying becomes feasible from areas of 22,595 ha. The cost of the outsourced aerial spraying service of 28.00 per hectare was more expensive, but this service increases $\mathrm{R} \$ 8.79$ per hectare in the revenue because it does not cause losses by crushing, being this amount discounted from the cost of the outsourced service. Thus, considering the losses due to crushing, the final cost of the outsourced service of $\mathrm{R} \$$ 19.21 per hectare was lower than the final production cost of the ground sprayer, which reached $\mathrm{R} \$ 20.93$ per hectare (Table 15).

TABLE 15. Costs of the outsourced service and ground spraying considering losses due to crushing (2018/19 growing season).

\begin{tabular}{lccc}
\hline & Production cost $(\mathrm{R} \$ / \mathrm{ha})$ & Crushing losses $(\mathrm{R} \$ / \mathrm{ha})$ & Final cost $(\mathrm{R} \$ / \mathrm{ha})$ \\
\hline Ground sprayer & 12.14 & +8.79 & 20.93 \\
Outsourced service & 28.00 & -8.79 & 19.21 \\
\hline
\end{tabular}


The option of outsourcing the aerial service has a lower production cost than the spraying model carried out on the farm because it does not cause losses due to the crop crushing, increasing the profitability despite being more expensive. Thus, contracting this service is feasible not only for cases that require emergency pesticide applications but also for spraying part of the area every growing season. Outsourcing is not indicated for the total area (exclusive use of third party services) due to the risks of delays to which the producer may be subject, such as lack of aircraft and weather restrictions, as well as the sudden increase in the cost of the outsourced service.

\section{CONCLUSIONS}

The economic indicators IRR, NPV, and PB of the Ipanema 203 model allowed concluding that this case study is feasible for implementation, as it has economic and financial feasibility, ensuring that the implementation of aerial spraying together with ground spraying on the farm can be profitable to the producer.

Regarding the variation in cost due to use, the production cost of ground spraying is lower than that of aerial spraying for up to 22,595 ha of sprayed area. Therefore, the cost of ground spraying is higher for larger areas, being the minimum area for technological replacement.

\section{REFERENCES}

Abi Saab OJG, Couto DTA, Higashibara LR (2007) Perdas de produtividade causadas pelo rodado de pulverizadores.

In.: Congresso Brasileiro da Ciência Aeroagrícola. Botucatu, FEPAF, Anais...

Araújo EC (2019) Perfil da aviação agrícola brasileira em 2018. Available: http://sindag.org.br/wpcontent/uploads/2019/05/Perfil-avia\%C3\%A7\%C3\%A3oagricola-brasileira-2018-versao-1.0.pdf. Accessed Out 22, 2019.

Artuzo FD, Foguesatto CR, Souza ARL, Silva LX (2018)

Gestão de custos na produção de milho e soja. Revista Brasileira de Gestão de Agronegócios 20(2): 273-294. DOI: http://dx.doi.org/10.7819/rbgn.v20i2.3192

ASABE (2011) Agricultural Machinery Management Data. In: ASABE standards: American Society of Agricultural And Biological Engineers, p385-390. D497.7

Antuniassi UR (2015) Evolution of agricultural aviation in Brazil. Outlooks on Pest Management, 26(1): 12-15. DOI: http://dx.doi.org/10.1564/v26_feb_04

Bayer T, Costa IFD, Lenz G, Zemolin C, Marques LN, Stefanelo MS (2012) Equipamentos de pulverização aérea e taxas de aplicação de fungicida na cultura de arroz irrigado. Revisa Brasileira de Engenharia Agrícola e Ambiental 15(2):192-198. DOI: http://dx.doi.org/10.1590/S1415-43662011000200007
Carvalho WPAD, Cunha JPARD (2019) Introdução à tecnologia de aplicação por via aérea. In: Antuniassi UR, Boller W. Tecnologia de Aplicação para Culturas Anuais. Passo Fundo, Aldeia Norte, 2 ed. cap.9, p.169-181.

Camargo TV, Antuniassi UR, Veiga M, Oliveira MAP (2008) Perdas na produtividade da soja causadas pelo tráfego de pulverizadores autopropelido. In: Simpósio Internacional de Tecnologia de Aplicação de Agrotóxicos. Ribeirão Preto, Instituto Agronômico de Campinas, $1 \mathrm{CD}$ ROM

Crepaldi SA (2016) Contabilidade rural: uma abordagem decisorial. São Paulo, Atlas, 8 ed: p.112-230.

Chechetto RG, Mota AAB, Antuniassi UR, Carvalho FK, Vilela CM, Silva ACA (2014) Caracterização da taxa de aplicação e pontas de pulverização utilizadas no Estado de Mato Grosso. Magistra 26: 89-97.

Farias MS, Schlosser JF, Estrada JS, Martini AT, Barbieri JP (2015) Critérios técnicos para a seleção de pulverizadores autopropelidos comercializados no mercado brasileiro. Ciência Rural 45(5): 939-942. DOI: http://dx.doi.org/10.1590/0103-8478cr20141179

Faro C (1979) Elementos de engenharia econômica. São Paulo, Atlas, 3 ed. ver.

Generoso F (2019) Comunicação pessoal. Cargo: Representate de vendas de aeronaves Embraer. Botucatu.

Hanna SO, Conley SP, Shaner GE, Santini JB (2007) Fungicide application timing and row spacing effect on soybean canopy penetration and grain yield. Agronomy Journal 100(5): 1488-1492. DOI: http://dx.doi.org/10.2134/agronj2007.0135

Hoffman R, Serrano O, Neves EM, Thaeme ACM, Engler JJC (1989) Administração da empresa agrícola. São Paulo, Pioneira, 6 ed: p. 180-213.

Lan Y, Shengde C, Fritz BK (2017) Current status and future trends of precision agricultural aviation technologies. Int J Agric \& Biol Eng 10(3): 1-17. DOI: http://dx.doi.org/10.3965/j.ijabe.20171003.3088

Martin F (2019) Comunicação pessoal. Cargo: IT manager, Post Sales and International Relationship of Aeroglobo Aeronaves. Botucatu, SP.

Vilela GM (2019) Comunicação pessoal. Cargo: Proprietário da fazenda utilizada no estudo. Mineiros, GO.

Oliveira SD, Ludwig MP, Crizel RL, Lemes ES, Filho OAL (2014) Amassamento durante o manejo do cultivo: Efeito no rendimento e na qualidade de semente de soja. Bioscience Journal 30: 1059-1069. ID: biblio-948362

Oliveira CM, Santana, AC, Homma AKO (2012) Os custos de produção e a rentabilidade da soja nos municípios de Santarém e Belterra, estado do Pará. Acta Amazonica 43(1): 23-32. DOI: http://dx.doi.org/10.1590/S004459672013000100004 
Oliveira VCD, Dalchiavon FC (2019) Investimentos na aplicação de defensivos agrícolas na reagião do MédioNorte do estado Matogrossense. Revista de ciências agrárias 42. DOI: http://dx.doi.org/10.19084/RCA18176

Silva TC (2019) Comunicação pessoal. Cargo: Cargo: Representate de vendas de aeronaves Air Tractor, Empresa Aviopeças, São Paulo, SP.
Spring J (2018) PIB do agronegócio do Brasil deve crescer $2 \%$ em 2019, prevê CNA. Reuters. Available: https://br.reuters.com/article/businessNews/idBRKBN1O4 24K-OBRBS. Accessed Jan 17, 2019

Zhang DY, Lan YB, Chen LP, Wang X and Liang D (2014) Current Status and Future Trends of Agricultural Aerial Spraying Technology in China. Transactions of the Chinese Society for Agricultural Machinery 45(10): 53-59. DOI: http://dx.doi.org/10.6041/j.issn.1000-1298.2014.10.009 